The Journal of Animal \& Plant Sciences, 31(1): 2021, Page: 97-102

ISSN (print): 1018-7081; ISSN (online): 2309-8694

\title{
CONTROLLED-RELEASE FERTILIZER AFFECTS GROWTH AND YIELD OF JAPONICA RICE
}

\author{
P. Hou ${ }^{1,2}$, L. Xue ${ }^{1}$, S. He ${ }^{1}$, Y. Zhou ${ }^{3}$, G. Li ${ }^{3}$, Y. Feng ${ }^{1}$, L. Yang ${ }^{1}$ and L. Xue $e^{1,2^{*}}$ \\ ${ }^{1}$ Key Lab of Agro-Environment in Downstream of Yangtze Plain, Ministry of Agriculture and Rural Affairs, Institute of \\ Agricultural Resources and Environment, Jiangsu Academy of Agricultural Sciences, Nanjing 210014, P. R. China \\ ${ }^{2}$ School of the Environment and Safety Engineering, Jiangsu University, Zhenjiang, 212001, P. R. China \\ ${ }^{3}$ College of Agronomy, Nanjing Agricultural University, Nanjing 210095, P. R. China \\ *Correspondence author's email: njxuelihong@gmail.com
}

\begin{abstract}
Resin-blending controlled-release fertilizer (RBB) is more consistent with the nutrient requirement of rice; the appropriate application rate though was unclear. To optimize the application rate of RBB for japonica rice in Tai-Lake region $\left(119^{\circ} 54^{\prime} \mathrm{E}, 31^{\circ} 17^{\prime} \mathrm{N}\right)$, China, the effects of different application rate of first time used to given in full on grain yield. When conducted in 2015 and 2016, four application rates of RBB, i) conventional application rate (RBB1, 270 $\left.\mathrm{kg} \cdot \mathrm{ha}^{-1}\right)$, ii) reduction by $10 \%\left(\mathrm{RBB} 2,243 \mathrm{~kg} \cdot \mathrm{ha}^{-1}\right)$, iii) reduction by $20 \%\left(\mathrm{RBB} 3,216 \mathrm{~kg} \cdot \mathrm{ha}^{-1}\right)$, and iv) reduction by $30 \%$ (RBB4, $\left.189 \mathrm{~kg} \cdot \mathrm{ha}^{-1}\right)$; and the control, split application of conventional fertilizers $\left(\mathrm{CN}, 270 \mathrm{~kg} \cdot \mathrm{ha}^{-1}\right)$, were employed. The results showed that compared with the $\mathrm{CN}$ treatment, a 10-30\% reduction of RBB enhanced the grain yield with the yield of RBB1 treatment $\left(9.23 \mathrm{t} \cdot \mathrm{ha}^{-1}\right)$ was the highest in 2015, when RBB3 $\left(9.72 \mathrm{t} \cdot \mathrm{ha}^{-1}\right)$ was the highest in 2016, due to higher panicle number. The larger panicle numbers and the high LAI and photosynthetic potential after anthesis were the main reasons for the higher yield. The results indicated that the application rate of RBB could be reduced to $189-216 \mathrm{~kg} \cdot \mathrm{ha}^{-1}$ without affecting the grain yield.
\end{abstract}

Keywords: japonica rice; resin blending controlled-release fertilizer; application amount; yield.

https://doi.org/10.36899/JAPS.2021.1.0197

Published online August 26, 2020

\section{INTRODUCTION}

Point source pollution and non-point pollution caused by human activities mainly were cause environment pollution (Wang et al., 2018). With the increasing public awareness and supervision, point pollution such as industrial wastewater and urban domestic sewage has been well-controlled. However, the rural non-point pollution has been becoming the main source of water pollution (Shen et al., 2015). For agriculture, excessive application of nitrogen fertilizer is the primary source for the non-point pollution duo to the low nitrogen utilization (Xue et al., 2013). The Tai-Lake region is an important paddy-upland rotation region. Farmers normally apply large amount of nitrogen fertilizers to obtain high yield (Wang et al., 2009). The previous research showed that the nitrogen loss of paddy fields in the Tai-Lake region with the conventional fertilizer rate $\left(270 \mathrm{~kg} \cdot \mathrm{ha}^{-1}\right)$ reached $85.8 \mathrm{~kg} \cdot \mathrm{ha}^{-1}$, which accounted for $31.8 \%$ of the nitrogen application (Xue et al., 2014). Therefore, to control the nitrogen loss, the research on the reduction technology of farmland nutrient inputs has been highlighted (Shang et al., 2014).

In the recent years, the slow/controlled release fertilizer has been developed (Azeem et al., 2014), which is a good alternative fertilizer for the balance of high yield and fertilizer application (Ke et al., 2017). The previous study found that with the same amount of nitrogen, the slow/controlled release fertilizer reduced the nitrogen loss in paddy fields compared with the conventional split fertilization. In addition, the resin blending controlled-release fertilizer (RBB) showed the best performance with the highest yield and lowest nitrogen loss (Hou et al., 2019). In addition, RBB was more consistent with the nutrient requirement of rice growth and beneficial for high yield (Miao et al., 2016). However, the application amount of RBB in current studies was the same of conventional urea rate. For bulk blending fertilizers, it is yet unclear whether the reduced dosage of RBB can still meet the needs of rice growth and maintain the yield. Therefore, it is necessary to study the effect of application rate of RBB on rice yield, to clarify the appropriate application rate of RBB for high yield and environmental protection.

\section{MATERIALS AND METHODS}

The experiment was carried out in 2015-2016 in Zhangdu Village, Yixing City, Jiangsu Province (119 $54^{\prime}$ E, $\left.31^{\circ} 17^{\prime} \mathrm{N}\right)$. The characteristics of the topsoil $(0-20 \mathrm{~cm})$ used for the experiment were: soil organic matter, 24.6 $\mathrm{g} \cdot \mathrm{kg}^{-1}$; total nitrogen, $1.42 \mathrm{~g} \cdot \mathrm{kg}^{-1}$; Olsen-P, 21.9 $\mathrm{mg} \cdot \mathrm{kg}^{-1}$; and available potassium, $72.2 \mathrm{mg} \cdot \mathrm{kg}^{-1}$. The 
precipitation and temperature during the experimental seasons were shown in Table 1.

The primary cropping regime for the experimental area is annual rice-wheat rotation; the soil type is a periodically waterlogged paddy soil. Soil preparation including tillage, irrigation, herbicide spraying etc. began after wheat harvesting. The experiment was a randomized split-plot design with three replications. Four different application rates of RBB treatments were set as the conventional application rate $\left(270 \mathrm{~kg} \cdot \mathrm{ha}^{-1}, \mathrm{RBB} 1\right), 10 \%$ reduced amount $\left(243 \mathrm{~kg} \cdot \mathrm{ha}^{-1}\right.$, RBB2), 20\% reduced amount (216 $\left.\mathrm{kg} \cdot \mathrm{ha}^{-1}, \mathrm{RBB} 3\right)$, and $30 \%$ reduced amount $\left(189 \mathrm{~kg} \cdot \mathrm{ha}^{-1}, \mathrm{RBB} 4\right)$. The split application of conventional chemical fertilizers (270 $\left.\mathrm{kg} \cdot \mathrm{ha}^{-1}, \mathrm{CN}\right)$ was set as the control. Each plot $(20 \mathrm{~m} \times 6$ $\mathrm{m})$ was separated by a ridge. The rice variety was Wuyunjing 23, a conventional japonica rice variety. The rice sown on 27 May 2015 and 30 May 2016 in nursery, then transplanted on 18 June 2015 and 20 June 2016 with the planting density of $30 \mathrm{~cm} \times 14 \mathrm{~cm}$. RBB was side-deep fertilized together with transplanting using the gas blowing type transplanting and side deep fertilizing integrated machine (Iseki\& Co., LTD. PZ60HVRASLF). The calcium super phosphorus $\left(129 \mathrm{~kg} \mathrm{P}_{2} \mathrm{O}_{5} \cdot \mathrm{ha}^{-1}\right)$ and potassium chloride $\left(200 \mathrm{~kg} \mathrm{~K}_{2} \mathrm{O} \cdot \mathrm{ha}^{-1}\right)$ were basal applied for all the treatments. Dry-wet alternate irrigation method was adopted.

The tiller dynamic was recorded periodically in the fixed point. From each plot, 10 consecutive holes were selected every week.

At jointing, heading and maturity stages, the tiller numbers of 40 hills were counted in each plot and 5 plant samples were collected for each plot. The leaf length and width were measured to calculate the leaf area index (LAI). The stems, sheaths, leaves and panicles of the plant were separated and fixed for 30 minutes at 105 ${ }^{\circ} \mathrm{C}$, then dried at $80^{\circ} \mathrm{C}$ to a constant weight, and the dry matter weight was measured. At maturity, a $4 \mathrm{~m}^{2}$ area without sampling in the plots was harvested and threshed with a small grain thresher to determine the grain yield (adjusted to a moisture content of 13.5\%).

Photosynthetic potential $\left(\mathrm{m}^{2} \cdot \mathrm{m}^{-2} \cdot \mathrm{d}^{-1}\right)$ $=(L 1+L 2) \times(t 2-t 1) / 2$, where, $L 1$ and $L 2$ are the leaf area per unit of field area measured before and after, and $t 1$ and $t 2$ are the time measured before and after.

The data were statistically analyzed using SPSS17.0 software, and the significance of difference was analyzed using Duncan method $(P \leq 0.05)$.

\section{RESULTS AND DISCUSSION}

Tiller dynamic of rice depends on and reflects the nutrient supply and water condition of paddy fields (Ling et al., 2000). There was a significant difference in tiller dynamic between years and treatments (Fig. 1). The population reached the peak of tiller number in 48 days after transplanting in 2015 and in 38 days in 2016. In addition, the peak seedling number in 2016 was obviously higher than that in 2015, but it fell sharply at later growth stages in 2016. The peak seedling number under flooding irrigation is often higher than that under dry-wet alternate irrigation method; by contrast, the percentage of productive tillers under flooding irrigation is often significantly lower (Liu et al., 2013). In this study, rice seedling grew in flooded environment at tillering stage due to the heavy and frequently rainfall in 2016 (Table 1). This may be the main reason for the higher peak seedling number and sharply fell at later growth stages in 2016.

It has been proved that $\mathrm{RBB}$ integrated resincoated urea of different release characteristic can release at all stages and is more consistent with the nutrient requirement of rice (Ke et al., 2017). By comparison, there was no significant difference in the tiller number among the treatments during the early tillering stage in 2015 due to the release characteristic of RBB. During the following stages, the tiller occurred faster under $\mathrm{CN}$ and RBB1, and the peak seedling number were $434 \mathrm{~m}^{-2}$ and $471 \mathrm{~m}^{-2}$ respectively, which were significantly higher than other treatments. After that, the tiller number with the $\mathrm{CN}$ treatment decreased rapidly. The tiller development rate, peak seedling number and panicle number with RBB treatments were significantly higher than those with $\mathrm{CN}$ treatment in 2016. This may be related to the runoff losses of inorganic fertilizers. In previous study, we have proved that the rainfall probability of basal fertilization stage and tillering fertilization stage were obviously higher than other stages in this region, implying high probability for paddy runoff in these two periods. Hence, the nitrogen loss from paddy field under $\mathrm{CN}$ treatment increased due to the easily soluble characteristics of urea and the heavy rainfall in 2016 (Hou et al., 2017a). The panicle number with reduced $\mathrm{RBB}$ treatments was significantly higher than those with $\mathrm{CN}$ and RBB1 treatment in 2016. The results indicated that regardless of rainfall during the growing season, there was no significant difference in the panicle number among the reduced RBB treatments, but the tiller development rate and peak seedling was different in different year.

The interactive effect of year and treatment on dry matter accumulation at different growth stage was not significant (Table 2). The dry matter weight at jointing and heading stages in $2015\left(3.65 \mathrm{t} \cdot \mathrm{ha}^{-1}, 8.38 \mathrm{t} \cdot \mathrm{ha}^{-1}\right)$ was significantly lower than that in $2016\left(4.67 \mathrm{t} \cdot \mathrm{ha}^{-1}, 9.83\right.$ $\left.\mathrm{t} \cdot \mathrm{ha}^{-1}\right)(P \leqslant 0.01)$. This may be related to the differences in tiller development rate and peak seedling (Fig. 1). When compared with all treatments, there was no significant difference in dry matter weight at heading and maturity stages among RBB treatments (Fig. 2). The dry matter accumulation in rice population is closely related 
to the leaf area and photosynthetic potential (Hossain et al., 2017). In present study, an increasing trend in LAI and photosynthetic potential for RBB treatments was observed. Particularly, the LAI at the heading stage was significantly higher under the RBB1 treatment in 2015 and RBB4 in 2016 than CN, which was helpful for the accumulation of photosynthate (Table 3 ). In addition, the LAI at heading stage was not significantly affected by the

Paddy water condition is the key factor affecting rice population (Khalid et al., 2018). Pan et al. (2009) documented that the water use efficiency and rice yield under dry-wet alternate irrigation were higher than that under flooding irrigation. It was also found that the rice years (Fig. 3). This may be related to the runoff losses of inorganic fertilizer due to the easily soluble characteristics of urea and the heavy rainfall in 2016. slow/controlled release fertilizers (sulfur-coated urea, resin-coated urea) under the controlled irrigation were higher than those under flooding irrigation. In the present study, the crop with RBB treatments had better stress resistance than $\mathrm{CN}$ treatment. This may be related to the nutrient release characteristics of the slow/controlled fertilizer type in the present study. Hou et al. (2017b) found that the nutrient release of sulfur-coated urea mainly happened in the early stage, while the nutrient release of RBB fertilizer was less affected by water and released evenly, which could meet the requirement of rice growth at different stages.

The application amount of RBB is mainly determined depending on the use of conventional urea (Miao et al., 2016). It is still unclear whether the reduction dosage can still meet the requirements of rice growth. The present study results showed that RBB reduction by $10-30 \%$ had a similar yield compared with $\mathrm{CN}$ treatment (Fig. 3). The yield (9.23 $\mathrm{t} \cdot \mathrm{ha}^{-1}$ ) under RBB1 treatment was the highest in the normal year, when the yield of RBB3 treatment was the highest $\left(9.72 \mathrm{t} \cdot \mathrm{ha}^{-1}\right)$ in the wet year. It has been suggested that the panicle different experimental years (Table 2). yield with $\mathrm{CN}$ in wet years was lower than that in normal Peng et al. (2014) found that rice yield with

number and grain number per panicle (sink size) is considered widely as well related to yield (Guo et al., 2018). The same has been indicated that the sink size formed at the early stage was the key factors that determined the yield in paddy fields with RBB; there was significant positive correlation between photosynthetic potential during transplanting to jointing stages and grain yield $(P \leqslant 0.05)$ (Table 4$)$. Although continuous heavy rains after transplanting resulted in a long-term flooding condition at tillering stage in 2016, the one-time deep application of RBB was conducive for yield stability (Table 2). Also, the dry matter accumulation from heading to mature stage was positively correlated with the yield (Ling, 2000). The present results suggested that the dry matter accumulation and yield with reduced RBB treatments were not decreased. The dry matter accumulation at the late stage can be represented by the LAI at heading stage (Ling, 2000). It also represents plants leaf photon interception, which highly influences biomass as well as yield production (Firouzabadi et al., 2015). The correlation analysis also indicated that the grain yield was positively correlated with LAI at heading stage (Table 4). Therefore, the higher LAI at the heading stage under RBB1 treatment in 2015 and RBB4 in 2016 may be the main reason for the difference in dry matter and yield among the treatments.

In conclusion, RBB proved to be a good alternative fertilizer to balance high yield and nutrients' wastage. The present results also highlight that application amount of RBB fertilizer in reference to conventional chemical fertilizer is overuse. $\mathrm{RBB}$ rate could be reduced by $20-30 \%$ to $189-216 \mathrm{~kg} \cdot \mathrm{ha}^{-1}$ without affecting grain yield of japonica rice in Tai-lake region. Rice varieties differ from each other in growth duration worldwide; the soil fertility and atmospheric environment also differ. The application rate of RBB in the present study may not be suitable for the other rice varieties. But, the opinion could provide a reference for selection and application of controlled release fertilizer for different types of rice in the world.
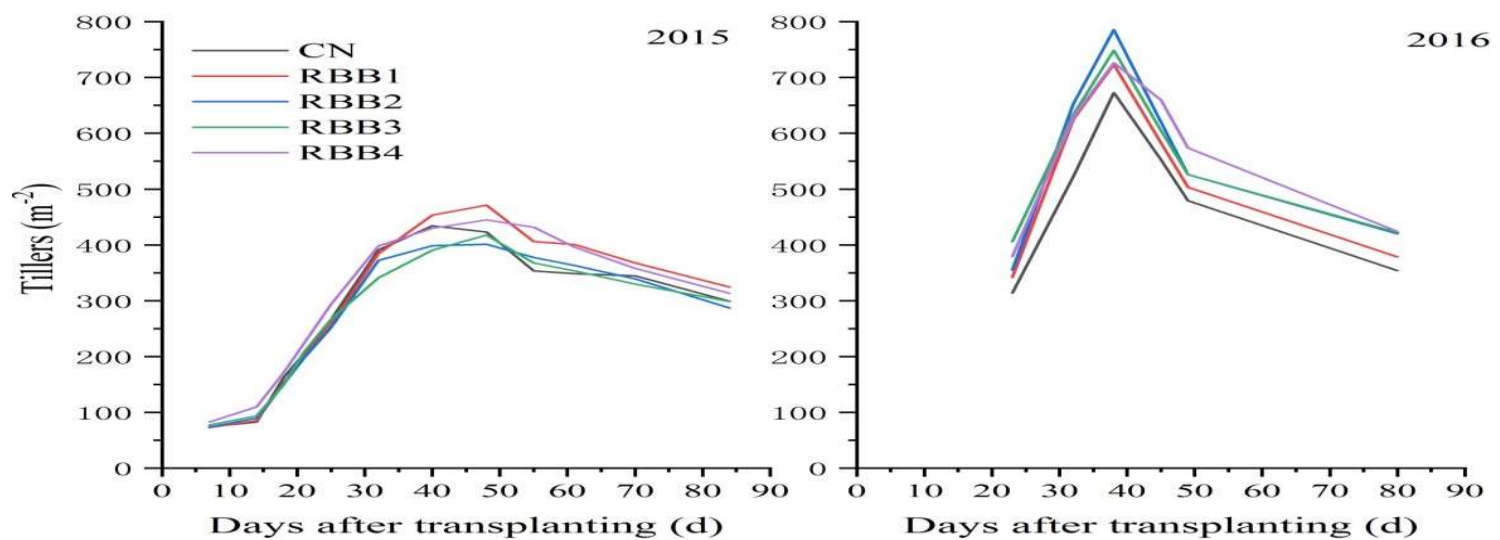

Fig. 1. Dynamic changes of tillers of reduced RBB treatments. 


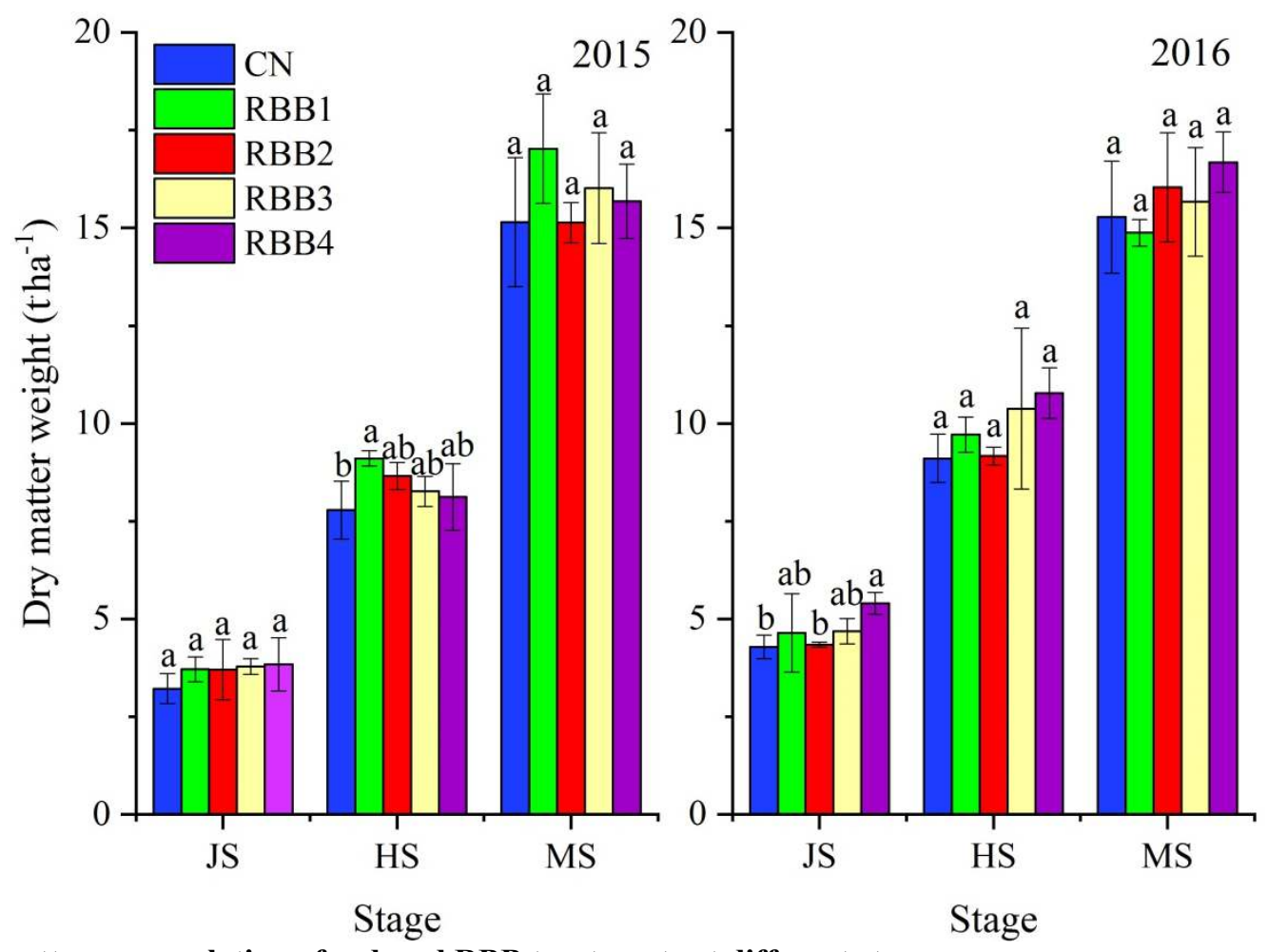

Fig. 2. Dry matter accumulation of reduced RBB treatments at different stages.

JS, jointing stage; HS, heading stage; MS, maturity stage. Different letters above the histogram indicate there are significant differences between different treatments at the $P \leq 0.05$ level (Duncan).
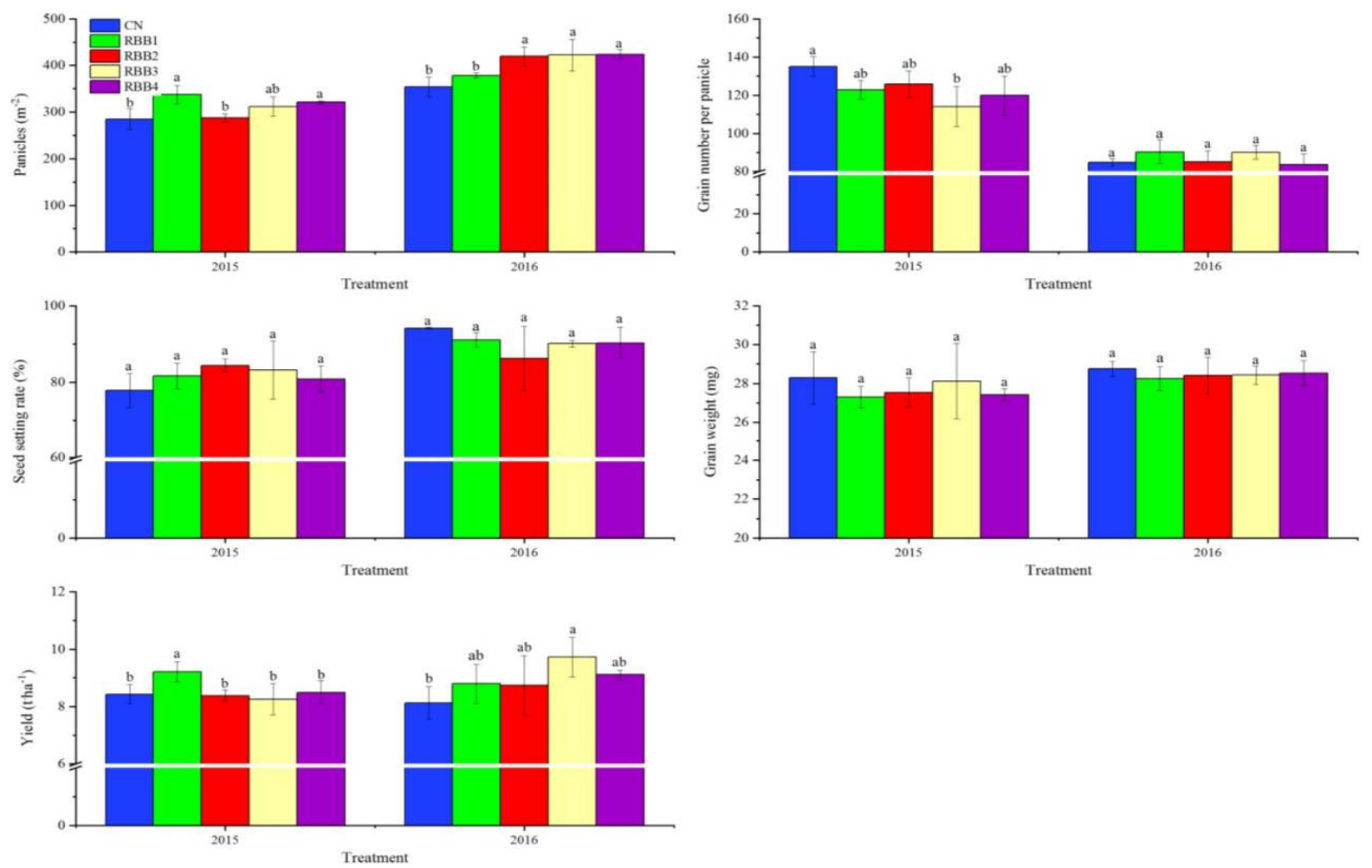

Fig. 3. Yield and its components of reduced RBB treatments.

Different letters above the histogram indicate there are significant differences between different treatments at the $P \leq 0.05$ level (Duncan). 
Table 1. Average daily temperature and cumulative precipitation of the experimental site during the rice growing season.

\begin{tabular}{ccc}
\hline Parameter & $\mathbf{2 0 1 5}$ & $\mathbf{2 0 1 6}$ \\
\hline Average daily temperature $\left({ }^{\circ} \mathrm{C}\right)$ & 24.3 & 25.4 \\
Cumulative precipitation $(\mathrm{mm})$ & 819 & 1530 \\
\hline
\end{tabular}

Table 2. Mean for the investigated variable and the factorial analysis.

\begin{tabular}{|c|c|c|c|c|c|c|}
\hline \multirow[b]{2}{*}{ Variable } & & \multicolumn{2}{|c|}{ Mean } & \multicolumn{3}{|c|}{$F$-value } \\
\hline & & 2015 & 2016 & $\begin{array}{c}\text { Year } \\
(Y)\end{array}$ & $\begin{array}{c}\text { Treatment } \\
\text { (T) }\end{array}$ & $\mathbf{Y} \times \mathbf{T}$ \\
\hline \multirow[t]{5}{*}{ Yield and its components } & Panicle number $\left(\mathrm{m}^{-2}\right)$ & 308.57 & 399.71 & $177.65^{* *}$ & $7.33^{* *}$ & $5.51^{* *}$ \\
\hline & Grain number per panicle & 123.47 & 86.79 & $233.67^{* *}$ & $1.59^{\mathrm{ns}}$ & $3.28^{*}$ \\
\hline & Seed setting rate $(\%)$ & 81.52 & 90.31 & $29.73^{* *}$ & $0.09^{\mathrm{ns}}$ & $2.08^{\mathrm{ns}}$ \\
\hline & Grain weight (mg) & 27.73 & 28.47 & $4.83^{*}$ & $0.59^{\mathrm{ns}}$ & $0.20^{\mathrm{ns}}$ \\
\hline & Yield $\left(\mathrm{t} \cdot \mathrm{ha}^{-1}\right)$ & 8.55 & 8.90 & $2.86^{\mathrm{ns}}$ & $1.86^{\mathrm{ns}}$ & $2.85^{\mathrm{ns}}$ \\
\hline \multirow[t]{3}{*}{ Dry matter weight $\left(\mathrm{t} \cdot \mathrm{ha}^{-1}\right)$} & JS & 3.65 & 4.67 & $29.65^{* *}$ & $2.29^{\mathrm{ns}}$ & $0.67^{\mathrm{ns}}$ \\
\hline & HS & 8.38 & 9.83 & $22.71^{* *}$ & $1.59^{\mathrm{ns}}$ & $1.93^{\text {ns }}$ \\
\hline & MS & 15.80 & 15.71 & $0.05^{\mathrm{ns}}$ & $0.57^{\mathrm{ns}}$ & $1.69^{\mathrm{ns}}$ \\
\hline \multirow[t]{2}{*}{ Leaf area index } & $\mathrm{JS}$ & 4.06 & 5.46 & $57.44^{* *}$ & $1.82^{\mathrm{ns}}$ & $0.38^{\mathrm{ns}}$ \\
\hline & HS & 7.11 & 7.19 & $0.31^{\mathrm{ns}}$ & $3.41^{*}$ & $4.01^{*}$ \\
\hline \multirow[t]{2}{*}{ Photosynthetic potential $\left(\mathrm{m}^{2} \cdot \mathrm{m}^{-2} \cdot \mathrm{d}^{-1}\right)$} & TS-JS & 113.79 & 136.42 & $22.43^{* *}$ & $1.84^{\mathrm{ns}}$ & $0.35^{\mathrm{ns}}$ \\
\hline & JS-HS & 134.10 & 183.38 & $221.85^{* *}$ & $3.90^{*}$ & $2.13^{\mathrm{ns}}$ \\
\hline
\end{tabular}

JS, jointing stage; HS, heading stage; MS, maturity stage; TS-JS, transplanting stage-jointing stage; JS-HS, jointing stage-heading stage. ${ }^{*} P \leq 0.05 ;{ }^{* *} P \leq 0.01$.

Table 3. Leaf area index and photosynthetic potential of reduced RBB treatment at different stages.

\begin{tabular}{|c|c|c|c|c|c|}
\hline \multirow{2}{*}{ Year } & \multirow{2}{*}{ Treatment } & \multicolumn{2}{|c|}{ LAI } & \multicolumn{2}{|c|}{ Photosynthetic potential $\left(\mathrm{m}^{2} \bullet \mathrm{m}^{-2} \bullet \mathrm{d}^{-1}\right)$} \\
\hline & & JS & HS & TS-JS & JS-HS \\
\hline \multirow[t]{5}{*}{2015} & $\mathrm{CN}$ & $3.85 \mathrm{a}$ & $6.78 b$ & $107.74 \mathrm{a}$ & $127.58 b$ \\
\hline & RBB1 & $4.36 \mathrm{a}$ & $7.96 \mathrm{a}$ & $121.97 \mathrm{a}$ & $147.84 \mathrm{a}$ \\
\hline & RBB2 & $3.87 \mathrm{a}$ & $6.64 b$ & $108.49 \mathrm{a}$ & $126.23 b$ \\
\hline & RBB3 & $3.98 \mathrm{a}$ & $7.01 \mathrm{~b}$ & $111.53 \mathrm{a}$ & $131.88 b$ \\
\hline & RBB4 & $4.26 \mathrm{a}$ & $7.16 b$ & $119.20 \mathrm{a}$ & $136.96 \mathrm{ab}$ \\
\hline \multirow[t]{5}{*}{2016} & $\mathrm{CN}$ & $4.90 \mathrm{a}$ & $6.73 b$ & $122.49 \mathrm{a}$ & $168.65 b$ \\
\hline & RBB1 & $5.57 \mathrm{a}$ & $7.01 \mathrm{ab}$ & $139.18 \mathrm{a}$ & $182.32 \mathrm{ab}$ \\
\hline & RBB2 & $5.44 \mathrm{a}$ & $7.28 \mathrm{ab}$ & $135.98 \mathrm{a}$ & $184.37 \mathrm{ab}$ \\
\hline & RBB3 & $5.46 \mathrm{a}$ & $7.44 \mathrm{ab}$ & $136.57 \mathrm{a}$ & $187.15 \mathrm{ab}$ \\
\hline & RBB4 & $5.91 \mathrm{a}$ & $7.49 a$ & $147.88 \mathrm{a}$ & $194.38 \mathrm{a}$ \\
\hline
\end{tabular}

LAI, leaf area index; JS, jointing stage; HS, heading stage; TS-JS, transplanting stage-jointing stage; JS-HS, jointing stage-heading stage. Different letters after the data represent that there are significant differences (Duncan) between different treatments at the level of $P \leq 0.05$.

Table 4. Correlation analysis between growth index and grain yield for the two years.

\begin{tabular}{lcccc}
\hline & $\begin{array}{c}\text { LAI at } \\
\text { JS }\end{array}$ & $\begin{array}{c}\text { LAI at } \\
\text { HS }\end{array}$ & $\begin{array}{c}\text { Photosynthetic } \\
\text { potential during TS-JS }\end{array}$ & $\begin{array}{c}\text { Photosynthetic } \\
\text { potential during JS-HS }\end{array}$ \\
\hline LAI at HS & $\mathrm{ns}$ & & & \\
Photosynthetic potential during TS-JS & $0.98^{* *}$ & $\mathrm{~ns}$ & $0.96^{* *}$ \\
Photosynthetic potential during JS-HS & $0.99^{* *}$ & $\mathrm{Ns}$ & $0.64^{*}$ & $\mathrm{~ns}$ \\
Yield & $\mathrm{ns}$ & $0.77^{* *}$ & ${ }^{*}$ & \\
\hline JS, jointing stage; HS, heading stage; TS-JS, transplanting stage-jointing stage; JS-HS, jointing stage-heading stage. ${ }^{*} P \leq 0.05 ;{ }^{* *} P \leq$ \\
0.01.
\end{tabular}


Acknowledgements: This work was supported by The National Key Research and Development Program of China (2017YFD0300104; 2016YFD0801101), The National Natural Science Foundation of China (41601319), National Science and Technology Major Project of China (2017ZX07202-004-03) and The Special Fund for Agro-scientific Research on Public Interests (201503106).

\section{REFERENCES}

Azeem, B., K.Z. KuShaari, Z.B. Man, A. Basit, and T.H. Thanh (2014). Review on materials \& methods to produce controlled release coated urea fertilizer. J. Control. Release. 181: 11-21.

Firouzabadi, A.G., M. Raeini-Sarjaz, A. Shahnazari, and H. Zareabyaneh (2015). Non-destructive estimation of sunflower leaf area and leaf area index under different water regime managements. Arch. Agron. Soil Sci. 61(10): 1357-1367.

Guo, T., K. Chen, N.Q. Dong, C.L. Shi, W.W. Ye, and J.P. Gao (2018). GRAIN SIZE AND NUMBERl negatively regulates the OsMKKK10-OsMKK4OsMPK6 cascade to coordinate the trade-off between grain number per panicle and grain size in rice. Plant Cell. 30(4): 871-888.

Hossain, S.A.A.M., L. Wang, T. Chen, and Z. Li (2017). Leaf area index assessment for tomato and cucumber growing period under different water treatments. Plant Soil Environ. 63(10): 461-467.

Hou, P., L. Xue, Y. Yu, Y. Jiang, J. Wang, L. Xue, and L. Yang (2017a). Nitrogen loss risk of paddy field under different fertilizations in runoff prone period. J. Agro-Environment Sci. 36(7): 1353-1361.

Hou, P., L. Xue, Y. Yu, L. Xue, L. Fan, and L. Yang (2017b). Control effect of side deep fertilization with slow-release fertilizer on ammonia volatilization from paddy fields. Environ. Sci. 38(12): 5326-5332.

Hou, P., L. Xue, Y. Zhou, G. Li, L. Yang, and L. Xue (2019). Yield and $\mathrm{N}$ utilization of transplanted and direct-seeded rice with controlled/slow-release fertilizer. Agron. J. 111(3): 1208-1217.

Ke, J., X. Xing, G. Li, Y. Ding, F. Dou, S. Wang, Z. Liu, S. Tang, C. Ding, and L. Chen (2017). Effects of different controlled-release nitrogen fertilisers on ammonia volatilisation, nitrogen use efficiency and yield of blanket-seedling machine-transplanted rice. Field Crop Res. 205: 147-156.

Khalid, H.M., I.F. Mahmod, S.S. Barakbah, and N. Osman (2018). Impact of water management on fertilizer and tillering dynamics in rice. Int. J. Agric. Biol. 20(1): 37-40.
Ling, Q. (2000). Crop population quality. Shanghai Scientific and Technical Publishers; Shanghai (China).

Liu, L., T. Chen, Z. Wang, H. Zhang, J. Yang, and J. Zhang (2013). Combination of site-specific nitrogen management and alternate wetting and drying irrigation increases grain yield and nitrogen and water use efficiency in super rice. Field Crop Res. 154: $226-235$

Miao, X., X. Xing, Y. Ding, J. Ke, Z. Liu, S. Tang, C. Ding, S. Wang, and G. Li (2016). Yield and nitrogen uptake of bowl-seedling machine-transplanted rice with slow-release nitrogen fertilizer. Agron. J. 108(1): 313-320.

Pan S.G., C.G. Cao, M.L. Cai, J.P. Wang, R.H. Wang, J. Zhai, and S.Q. Huang (2009). Effects of irrigation regime and nitrogen management on grain yield, quality and water productivity in rice. J. Food Agric. Environ. 7(2): 559-564.

Peng, Y., Y. Sun, M. Jiang, H. Xu, J. Qin, Z. Yang, and J. Ma (2014). Effects of water management and slow/controlled release nitrogen fertilizeron biomass and nitrogen accumulation, translocation, and distribution in rice. Acta Agron. Sin. 40(5): 859-870.

Shang, Q., C. Gao, X. Yang, P. Wu, N. Ling, Q. Shen, and S. Guo (2014). Ammonia volatilization in Chinese double rice-cropping systems: a 3-year field measurement in long-term fertilizer experiments. Biol. Fert. Soils. 50(5): 715-725.

Shen, Z.Y., Y.C. Zhong, Q. Huang, and L. Chen (2015). Identifying non-point source priority management areas in watersheds with multiple functional zones. Water Res. 68: 563-571.

Wang, H., Y. Xi, R. Chen, X. Xu, Q. Wei, and J. Li (2009). Investigation on excessive application of fertilizer and pesticides in Taihu Lake region. AgroEnvironment \& Dev. 26(3): 10-15.

Wang, Y., J. Yang, J. Liang, Y. Qiang, S. Fang, and M. Gao (2018). Analysis of the environmental behavior of farmers for non-point source pollution control and management in a water source protection area in China. Sci. Total Environ. 633: 1126-1135.

Xue, L., L. Yang, W. Shi, and S. Wang (2013). Reduceretain-reuse-restore technology for controlling the agricultural non-point pollution in countryside in China: source reduction technology. J. AgroEnvironment Sci. 32(5): 881-888.

Xue, L., Y. Yu, and L. Yang (2014). Maintaining yields and reducing nitrogen loss in rice-wheat rotation system in Taihu Lake region with proper fertilizer management. Environ. Res. Lett. 9(11): 115010 . 